\title{
Miksi tutkia
}

\section{venäjän kieltä Suomessa?}

\author{
Johanna Viimaranta
}

Luentoni aihe on provosoivasti "Miksi tutkia venäjän kieltä Suomessa?" Koska olen kieli-ihminen, on valitsemani otsikko harkitusti monitulkintainen. Käsittelen esityksessäni kahta teemaa. Ensinnäkin käsittelen kysymystä, miksi tutkia venäjän kieltä nimenomaisesti Suomessa eli mikä osa Suomessa tehtävällä tutkimuksella on venäjän kielen tutkimuksessa laajemmin ja mikä on tai voisi olla kielitieteen anti osana suomalaista Venäjä-tutkimusta. Toiseksi perustelen, miksi Suomessa puhuttava venäjän kieli on olennainen tutkimuskohde.

Aloitan siitä, miksi tutkia venäjän kieltä Suomessa. Venäjä on yksi maailman tutkituimmista kielistä. Perustutkimusta ei siis puutu. Välillä tuntuu siltä, että kaikki kivet on jo käännetty. Suomalaisessa venäjän kielen tutkimuksessa katse on kuitenkin onnistuneesti ulkopuolisen katse. Suomalaiset venäjän kielen tutkijat tutkivat usein aiheita, joita venäjänkieliset, venäjän kieleen keskittyneet kielentutkijat Venäjällä eivät havaitse tai joiden kohdalla he eivät kykene irrottautumaan totutuista selitysmalleista. Suomalaiselle venäjän kielen tutkimukselle eli rusistiikalle on tyypillistä myös laajasti muita kieliä huomioon ottava paradigma, mikä lienee muun muassa suomalaisten laajan kielitaidon ansiota. Suomalaisessa venäjän kielen tutkimisessa tullaan toistuvasti kiistanalaisiin johtopäätöksiin, mikä on omiaan uudistamaan tiedettä. Lisäksi me julkaisemme kansainvälisesti useilla eri kielillä, etenkin venäjäksi ja englanniksi. Suomalaiset venäjän kielen tutkijat ovat näin ollen omalla alallaan kiistattomasti arvostettuja. Käyttäisin jopa tuttua metaforaa ja sanoisin, että suomalaiset venäjän kielen tutkijat ovat tutkimuksen eturintamassa.

Mikä sitten on kielentutkimuksen anti kuuluisalle suomalaiselle Venäjä-tutkimukselle laajemmin? Toivon kaikkien tiedostavan, että kielellä on muukin kuin puhtaan välineellinen 
viestintäarvo. Ihmisen älyllinen toiminta on tiukasti sidoksissa kieleen, ja näin ollen ymmärrys kielestä ja sen toiminnasta hyödyttää laajasti ihmis- ja muitakin tieteitä. Kielitieteellinen analyysi perustuu myös aina muuttamattomiin venäjänkielisiin alkuperäisaineistoihin, jo vähintään yhden valinta- ja tulkintaprosessin läpikäyneiden englanninkielisten materiaalien sijaan.

Kielentutkijan osaamisaluetta ovat tieto kielen eri rakenneosista ja tasoista; sanan osat, niiden merkitys, alkuperä, funktiot; sanojen yhdistyminen lausumiksi ja lauseiksi; saman merkityssisällön eri ilmaisumahdollisuudet ja niiden erot kieliä vertailtaessa; tekstin rakentumisen ja vaikuttavuuden elementit ja diskurssit, merkitykset, merkityksellistämisen prosessit. Me osaamme ottaa huomioon kielen yksilöllisen ja sosiaalisen variaation ja tiedämme kielen muutoksen lainalaisuuksista. Näin pystymme asettamaan tutkittavan tekstin sen kielelliseen kontekstiin, jonka tulee vaikuttaa sen tulkintaan. Tiedämme, minkälaiset prosessit vaikuttavat eri tulkintojen syntymisessä. Toki olemme myös kielen oppimisen ja opettamisen asiantuntijoita.

Annan esimerkin siitä, millaisia asioita kielentutkija saa irti lyhyestäkin tekstistä. Esimerkkitekstini on Ylen venäjänkielisiltä uutissivuilta. Tekstipätkässä, joka on artikkelin alku heti otsikon ja ingressin jälkeen, kerrotaan uutinen Finlandia-palkinnon voittajasta. Tekstin voi kääntää näin:

Finlandia-kirjallisuuspalkinnon sai tänä vuonna Olli Jalonen romaanistaan "Taivaanpallo".

Kyseessä on jo toinen kerta, kun hänet palkitaan tällä arvostetuimmalla suomalaisella

kirjallisuuspalkinnolla. Edellisen kerran hän sai palkinnon vuonna 1990.

Muulle kuin kielitieteilijälle tämä asiasisällön suurin piirtein oikein välittävä käännös riittäisi, etenkin kun tekstin tyyli on kaikin puolin neutraali. Vaikka tekstin konteksti on moneen tutkimuskysymykseen liian niukka, löydämme tekstinpätkästä tästä huolimatta yhtä jos toistakin kiinnostavaa.

Tekstiä voi tutkia ensinnäkin kieliopillisesta sanojen ja niiden osien funktioiden näkökulmasta: millaisista merkityksiä ja funktioita sisältävistä osista sanat muodostuvat ja miten nämä osat liittävät sanat toisiinsa ja muihin sanoihin. Näinkin lyhyt teksti sisältää kymmenittäin erilaisia säännönmukaisesti toistuvia kieliopillisia osasia. Toisaalta tekstin etenemistä voi tutkia muun muassa perinteisen lauseenjäsennyksen, sanajärjestyksen avulla tapahtuvan argumentaation rakentumisen tai tekstin sisältämien siirtymäkohtien avulla.

Tekstissä on myös mielenkiintoisia arvottavia sanavalintoja kuten sana "jo" kerrottaessa Jalosen saaneen palkinnon toista kertaa ja Finlandia-palkinnon kuvaus "arvostetuimmaksi suomalaiseksi kirjallisuuspalkinnoksi”. Tekstistä löytyy lisäksi kirjoittajan näkökulman osoittavia rakenteita. Käytetyt verbimuodot osoittavat, että näkökulma tekstissä on palkinnon saajan - palkinnon "sai" Jalonen, hänet "on palkittu" ja "hänestä tuli" palkinnon haltija. Yhtä lailla kirjoittaja olisi voinut valita muunkin näkökulman.

Tässä oli siis muutamia esimerkkejä kielitieteellisestä tempusta ja siitä, miten se tehdään. Mitä merkitystä tällä siis on? Edustamani kognitiivinen kielitiede olettaa, että kielen kaikkien tasojen ilmiöt ovat yhtä lailla todistusvoimaisia taustalla olevan käsitteistyksen toiminnasta. Käsitteistys tarkoittaa sitä tapaa, miten ihminen jaottelee, kategorisoi aistiensa avulla saamaansa tietoa. Kielen käytössä on täten paljon tiedostamatonta mutta merkityksellistä. Kielen käyttäjällä ei ole todellista valintatilannetta, hän voi jossain määrin tietoisesti valita esimerkiksi kahden lähimerkityksisen sanan välillä, mutta hänen kielitajunsa määrittelee 
suurimman osan kielenkäytöstä, mikä onkin täysin automatisoitunutta. Kieli heijastaa ajattelua ja kielen säännönmukaisuudet kertovat kielikohtaisista käsitteistysmalleista, jotka opitaan kieltä omaksuttaessa. Mikään kielessä ei siis ole sattumanvaraista. Kielen pienen pienillä nyansseilla alkaen sananmuodostuksesta, sanavalinnoista ja rakenteista tuodaan esiin huomionarvoisia seikkoja, jotka jäävät helposti muilta kuin kieliammattilaisilta huomaamatta.

Esitänkin täten tieteellisen haasteen. Haastan Suomen muiden tieteenalojen Venäjätutkijoita tekemään enemmän yhteistyötä venäjän kielen tutkijoiden kanssa riippumatta siitä, kiinnostavatko heitä varsinaiset kielitieteelliset kysymyksenasettelut. Tällaisen yhteistyön tuloksena on toki kutakin tarkoitusta konkreettisesti palveleva, mutta väistämättä laajaalaisempi, syvällisempi ja muodikkaan poikkitieteellinen Venäjä-tutkimuksen aineistojen analyysi. Muun muassa monilla tieteenaloilla suositun diskurssianalyysin menetelmiä käytettäessä kielen tason analyysi jää usein ilman kielitieteilijöitä hyvin köyhäksi.

Siirryn luentoni toiseen osioon. Miksi siis ottaa tutkimusaiheeksi Suomessa puhuttava venäjän kieli? Aloitan perusteluni Suomen tämänhetkisellä kielitilanteella. Tilastokeskuksen mukaan vuoden 2017 lopussa Suomessa asui pysyvästi 77000 henkilöä, joiden äidinkieleksi oli ilmoitettu venäjä. Todellisuudessa venäjää puhuvien määrä on monien kaksikielisten perheiden ansiosta vielä huomattavasti suurempi, sillä kullakin kun voi olla vain yksi virallinen äidinkieli. Venäjää puhutaan siis Suomessa eniten heti suomen ja ruotsin jälkeen. Venäjänkielisten määrä alkoi rajusti kasvaa 1990-luvulta alkaen ja tämä kehitys jatkuu edelleen. Mielestäni tähän on pystyttävä vastaamaan muutenkin kuin aikansa eläneillä asenteilla.

Keitä siis ovat Suomen venäjänkieliset? On tärkeää tiedostaa, että kyseessä on monikulttuurinen ja heterogeeninen ryhmä, johon kuuluu myös muiden kansallisuuksien edustajia kuin venäläisiä. Venäjänkielisten joukossa on eri aikoina eri paikoista eri syin Suomeen tulleita. Heillä on vaihteleva kielellinen ja kulttuurinen identiteetti, josta valtaväestöllä ei ole tietoa. Monet heistä venäläistyvät eli identifioituvat vahvemmin venäläiseen kulttuuriin Suomeen tulonsa jälkeen. Venäjänkieliselle vähemmistölle on tärkeää integroitua, mutta en soisi heidän assimiloituvan, koska he ovat Suomelle tärkeä resurssi. Tämän resurssin vaalimiseksi venäjän kielen vaaliminen Suomessa on ensiarvoisen tärkeää, koska ilman asianmukaista äidinkielenopetusta Suomessa syntyneet venäjänkieliset ovat vaarassa jäädä puolikielisiksi ja hylätä äidinkielensä viimeistään seuraavassa sukupolvessa. Tästä on Suomen vinoutuneessa asenneilmapiirissä valitettavan paljon esimerkkejä.

Asenteisiin venäjän kieltä ja venäjänkielisiä kohtaan kielentutkija voi vaikuttaa korkeintaan tietoa antamalla. Haluankin tässä tuoda esiin niitä epäkohtia, joita liittyy venäjän kielen opetukseen Suomessa. Viimeiseksi käsittelen vielä suomenvenäjää kielimuotona.

Venäjän kielellä ei ole virallista asemaa Suomessa eikä sen opetusta äidinkielenä täten taata. Oppilailla on tämän takia eri kunnissa ja jopa kuntien sisällä eri kouluissa eriarvoinen asema. 80 prosentissa suomalaisista kouluista ei tarjota ollenkaan muiden kielten kuin maan virallisten kielten opetusta äidinkielenä. Myös venäjä äidinkielenä -oppikirjojen tilanne on huono, koska Suomessa kasvaneiden venäjänkielisten erityistarpeet huomioon ottavalla oppikirjatyöllä ei ole resursseja. Myös venäjän opettaminen vieraana kielenä on erittäin suhdanneherkkää ja jää usein säästökohteeksi. Tämä siitä huolimatta, että virallisten puheiden tasolla venäjä on tärkeä osa Suomen kielivarantoa. Venäjän kielen opettamisen ja oppimisen tutkimus Suomen kontekstissa on sekin vielä vähäistä aiheen yhteiskunnallisesta relevanssista huolimatta.

Mitä on suomenvenäjä, johon viittasin tutkimuskohteena? Onko olemassa suomenvenäjä erillisenä kielimuotona? Tätä voisi verrata esimerkiksi ruotsinsuomeen tai amerikansuomeen, 
joista meillä monilla on kokemusta. Tiedämme niiden poikkeavan siitä suomesta, jota puhumme täällä Suomessa. Suomenvenäjän kielellisiä erityispiirteitä ovat ensinnäkin monien venäjän muotojen (ei vain Moskovan standardivenäjän) rinnakkaiselo. Toisaalta suomi ja jossain määrin myös ruotsi ovat vaikuttaneet suomenvenäjän sanastoon ja rakenteisiin. Uskon, että tutkimukseen perustuva tieto suomenvenäjän käytöstä ja rakenteesta sekä venäjänkielisen väestön kieli- ja kulttuuri-identiteetistä antaa pohjan negatiivisen segregaatiokehityksen katkaisemiselle. Suomi tarvitsee venäjänkielisiään.

Miksi siis Suomen näkökulmasta tutkia venäjän kieltä Suomessa? Kielentutkijat toki löytävät oman motivaationsa, mutta mikä on se yleisempi hyöty? Vastaukseni on, että venäjän kielen tutkimus lisää ymmärrystä sekä Venäjästä että monikulttuurisesta ja -kielisestä Suomesta.

Johanna Viimaranta piti uuden professorin tervetuliaisluennon Helsingin yliopistossa 5.12.2018. Tallenne luennosta on katsottavissa osoitteessa https:/www. helsinki.fi/fi/unitube/video/21021 